\title{
GERAKAN MUSLIM PROGRESIF PASCA REJIM SUHARTO DI INDONESIA
}

\author{
Ahmad Suaedy \\ Direktur Eksekutif The Wabid institute Jakarto
}

\begin{abstract}
Abstrak
Di luar tumbubnya berbagai gerakan Islam radikal dan fundamentalis paska tumbangnya Orde Baru, muncul pula gerakan Muslim progresif. Sebuah gerakan yang mengusung berbagai isu substansial untuk demokrasasi seperti pluralisme dan toleransi, hak-hak perempuan dalam Islam dan keadilan, atau hakhak asasi manusia pada umumnya. Sebagian mereka tumbub berkat keterbukaan politik di era reformasi, tetapi sebagian lainnya merupakan penjelmaan dari gerakan underground di era orde baru yang mengusung demokratisasi dengan titik masuk Islam. Kini mereka trerbangun jaringan kerja baik dalam level isu untuk mempertajam dan menggugat konsep-konsep konvesional tentang Islam mengiringi perubahan sosial politik, maupun dalam prkatik politik itu sendiri untuk menjaga sustainabilitas demokrasi. Bagaimanakah jaringan itu terbangun, bagaimana cara kerja mereka, isu apa saja yang mereka usung dan apa kelebihan dan kekuranagnnya, serta bagaimana prospek gerakan ini? Itulah beberapa masalah pokok yang bendak disajikan dalam presentasi ini.
\end{abstract}

Kata kunci; Muslim progresif, pasca orde baru, gerakan Islam

\section{Pendahuluan}

Sesungguhnya tidak ada istilah baku untuk Gerakan Muslim Progresif (GMP) ini. Ada banyak variasi pendapat yang diamksud dengan Muslim Progresif. Kita mungkin bisa mengacu pada pendapat dua orang, yaitu Dr. Fariz A. Noor (2006) dari Malaysia dan Dr. Omid Safi (2003). Fariz membukukan tulisannya ini di Indonesia yang cukup panjang tentang ini yang sebelumnya telah beredar luas di mailing list Muslim progresif. Sedangkan Safi menulis buku yang merupakan kompilasi dari berbagai tulisan para intelektual dan aktivis Muslim progresif dari negaranegara Islam yang tinggal di Amerika.
Secara singkat dua penulis ini memberikan beberapa ciri dari gerakan Muslim Progresif. Yaitu mereka yang cukup kritis terhadap situasi global dan ketidakadilan yang diakibatkannya dan juga concern untuk menegakkan keadilan di wilayah dimana mereka hidup dan bertempat tinggal; sebagai dasar dari kritisisme dan concern di atas, mereka juga kritis terhadap modernisme atau fenomena modernisasi pada umumnya; ciri lainnya adalah memiliki kepedulian sebagai titik tolak dan sekaligus kritis terhadap tradisi Islam yang panjang; dan ciri berikutnya adalah mereka tidak hanya bertengger di menara gading sebagai intelektual tetapi juga ikut terjun langsung 
dalam proses penyadaran dan menggerakkan masyarakat.

Dua-duanya, baik Fariz maupun Safi memiliki tekanan yang berbeda. Fariz menekankan pentingnya para aktivis Muslim Progresif ini untuk memberikan perhatian yang besar kepada fenomena globaliasi dan kritik terhadapnya dengan serta merta menggabungkan diri kepada kelompok anti-globalisasi. Menurut Fariz, tanpa itu, maka GMP akan kehilangan relevansinya dan tidak akan bisa berbuat banyak kepada masyarakatnya. Fariz juga menekankan pentingnya legitimasi keagamaan, termasuk dalam istilah-istilah teknis keagamaan atau teologis, terhadap tujuan perubahan itu sendiri seperti demokrasi dan anti-globaliasi. Ini dimaksudkan untuk mengimbangi kelompok rekasioner dan konservatif yang mengedepankan dan menggunakan termterm keagamaan Islam untuk melegitimasi misi dan cara pandangnya.

Sementara Safi, meskipun tidak mengabaikan apa yang dikemukakan oleh Fariz, tampaknya lebih menekankan pada usaha penyadaran baik secara intelektual maupun gerakan atas fenomena ketimpangan sosial secara rasional dan pandangan yang lebih terbuka bagi kaum Muslimin. Dengan demikian, para intelektual bersama-sama dengan masyarakat terlibat dalam proses analisis sosial dan gerakan perubahan itu sendiri. Safi mengidentifikasi tiga tema besar dalam gerakan MP ini, yaitu keadilan, pluralisme dan kesataraan gender.
Konteks Gerakan Muslim Progresif di Indonesia

Seacara historis di Indonesia, kebijakan otoritarianisme dan anti-ideologi atau dekonfessionalisasi Orde Baru (Effendy, 1998, p. 23-26) telah mempercepat terbangunnya kelompokkelompok muda yang menyediakan diri untuk bekerja dalam wilayah sosial dengan mengambil jarak tertentu atas partai politik yang dipasung oleh pemerintah; dunia usaha yang penuh dengan manipulasi dan kolusi; serta menolak sebagai birokrat atau aparat Negara yang represif. Karena itulah gerakan mereka yang lebih banyak bergabung kelompokkelompok independen dan nongovernmental organisasi (NGO) umumnya menjadi marak di akhir kekuasaan Orde Baru.

Namun perubahan politik di Indonesia pasca reformasi 1998 telah mengubah pula peran dan arah kecenderungan gerakan tersebut. Jika masa Orde Baru kelompok-kekompok dan NGO tersebut, termasuk kelompokkelompok dan NGO Islam, ikut terlibat dalam penyadaran masyarakat dan bahkan pengerahan massa untuk menantang dan menggulingkan Orde Baru, dengan demikian berhadapan langsung dengan pemerintahan yang otoriter dengan segala strateginya (Uhlin, 1995; Eldridge, 1995; Budiman et. al., 2001), maka pasca reformasi mereka harus berhadapan pula dengan kekuatan sosial yang bangkit akibat dibukanya kran demokrasi. 
Kran demokratisasi pasca reformasi itu setidaknya dibuka melalui beberapa Undang-Undang politik yang penting. Di antaranya, yaitu pemilu yang multipartai (UU tentang Partai Politik No. 31/Th. 2004) yang diselenggarakan dengan relatif bebas dan dilaksanakannya pemilihan langsung presiden/wakil presiden (UU tentang Pemilihan Presiden dan Wakil Presiden No. 23/Th. 2003). Indikasi lainnya adalah diterapkannya Otonomi Daerah dan Pilkadasung (UU No. 25 th. 2004 dan UU No. 32 Th. 2004) secara bertahap di seluruh Indonesia sebagai salah satu realisasi penting dari UU otonomi daerah tersebut. Pilkadasung itu dimulai sejak 2005.

Respon terhadap dibukanya kran demokrasi itu ternyata memunculkan sisi lain. Salah satunya, misalnya, munculnya secara cukup kuat politik identitas; politik aliran dalam partai-partai politik; menguatnya konservativme Islam; serta kelompok-kelompok fundamentalisme Islam (Fealy at. al., 2005; Barton, 2004). Karena itu kelompok-kelompok progresif Islam dipaksa untuk melakukan reposisi, tidak lagi secara vis a vis berhadapan dengan pemerintah sebagai penguasa represif melainkan juga berhadapan dengan kelompok-kelompok tersebut yang seringkali menggunakan massa dan juga institusi-institusi demokrasi seperti pemilu, parlemen, lagislasi dan birokrasi untuk kepentingan agenda non-demokrasi dan berhadapan dengan kelompok prodemokrasi.
Di sisi lain, ada kelemahan yang mendasar pula dalam tata kelola pemerintahan (good governance). Meskipun pemerintah dipilih secara demokratis belum tentu ia melaksanakan prinsipprinsip good governance dalam praktiknya. Tidak adanya lagi sandaran otoritarianisme militer dan partai mayoritas tunggal (Golongan Karya) seperti pada era Orde Baru, diiringi dengan lemahnya profesionalisme dan merit system, membuat para penguasa baru itu mencari sandaran dan patron sebagai alat hegemoni baru berupa politik identitas dan politik aliran, terutama agama dan etnis, termasuk agenda-agenda yang disodorkan kelompok konservatif dan fundamentalis agama. Pendekatan primordialisme, identitas agama, etnis dan kedaerahan, serta kelompok menjadi fenomena jamak politik baru Indonesia.

Tak pelak lagi fenomena ini bertemu dengan ide-ide konservatisme keagamaan dan identitas politik kelompok. Bahkan kecenderungan ini sengaja maupun tidak seringkali bertemu dengan kecenderungan gerakan internasional fundamentalisme (Fealy at. al., 2005, p. 47-90). Dengan demikian, sulit untuk dikatakan pemilu dengan multipartai yang terbuka, pilpres (pemilihan presiden) langsung dan pilkadasung (pemilihan kepala daerah langsung) pasca reformasi, semata-mata merupakan representasi dari kemajuan demokrasi dalam artinya yang substansial dalam pola rekrutmen, relasi dan 
professional dalam praktik politik Indonesia mutakhir.

Yang terjadi adalah unsur-unsur tradisional seperti primordialisme, politik identitas dan hegemoni politik aliran menumpang dalam prosedur demokrasi dengan segala turunannya. Munculnya berbagai aturan yang tanpa partisipasi masyarakat, dan malah cenderung mengorbankan kebebasan dan kepentingan rakyat banyak, serta kecenderungan memasukkan unsur-unsur moralitas individu agama dalam legislasi, memombilisasi massa dengan politik identitas dan politik aliran, merupakan bukti nyata akan adanya kecenderungan ini.

Gerakan Islam progresif dan NGO Muslim tersebut menjadi bagian dari pergulatan ini. Di samping melakukan koreski dan kritis terhadap kecenderungan mismenejmen pemerintahan dari sudut goad governenace, juga berhadapan dengan kelompok-kelompok radikal dan fundamentalis yang seringkali berkelindan dengan para birokrat agama dan politisi. Terutama ketika kelompok progresif ini memperkenalkan nilai-nilai utama demokrasi melalui pengenalan dan pembongkaran diskursus baru keagamaan. Mereka, dengan demikian, bukan hanya berhadapan dengan kecenderungan pemerintahan dan birokrasi yang bergandeng tangan dengan Islam konsrervatif dan fundamentalis melainkan juga sering berhadapan dengan lembagalembaga atau organisasi-organisasi keagamaan dan partai politik berbasis aliran.

Karena itu, demokrasi prosedural yang telah tercapai oleh Indonesia sejuah ini belum memuaskan sebagian besar dari gerakan Muslim progressif. Apa yang dibutuhkan adalah peran yang lebih substansil dari unsur-unsur civil society di dalam masyarakat dalam mengontrol pemerintah di satu pihak dan mendorong partisipasi rakyat dan grass-root di lain pihak (Eldridge, 1995, p.5-7; Hefner, 2000, p.1314). Seperti dikatakan Hafner:

Democracy requires a noncoercive culture that encourages citizens to respect the rights of others as well as to cherish their own. This public culture depends on mediating institutions in which citizens develop habits of free speech, participation, and toleration (Hefner, 2000, p. 13).

Pada saat yang sama sebenarnya sedang muncul generasi baru gerakan Islam tersebut bersamaan perubahan cepat yang sedang terjadi pasca tumbangnya Suharto 1998.

“Gerekan Muslim Progresif” di Indonesia bisa merujuk pada kelompokkelompok Muslim yang secara voluntary berusaha menegakkan prinsip-prinsip demokrasi yang berangkat dari nilai-nilai Islam serta mendorong partisipasi umat Islam dalam proses perubahan sosial politik menuju demokrasi. Ia sendiri menyerupai NGO (Non-Governmental Organization) yang sering didefinisikan sebagai kelompok sosial yang bukan berasal dari pemerintahan, partai politik, 
dan bukan kelompok usaha untuk mencari untung (Eldridge, 1995, p. 1-2; GanieRochman, 2002, p. 5; Fakih, 1996, p. 3-4).

Mereka bisa terdiri dari kelompok kajian ilmiah, kelompok aktivis mahasiswa, kelompok pekerja sosial dan bisa jadi kelompok profesi, tetapi bukan terdiri dari kelompok humanitarian seperti palang merah dan bukan pula pekerja kesehatan. Meskipun kelompok seperti ini, termasuk di kalangan masyarakat Islam, di Indonesia sudah muncul sejak awal abad ke-19 sebagai respon atas penjajahan dan untuk memperjuangkan kemerdekaan -kemudian sebagian mereka menjelma menjadi partai politik Islam atau organisasi massa Islam (Rahardjo, 1999). Tetapi dimaksud di sini adalah kelompokkelompok yang tumbuh dan berkembang sebagai respon atas pembangunan di Indonesia tahun 1970an (Fakih 1996, p. 34; Eldridge, 1995, p. 177-182; GanieRochman, 2002, p. 6-7).

Khusus dalam isu Islam atau kelompok Islam atau NGO-NGO Islam, maka gerakan ini tampaknya bisa dirunut sejak berdirinya divisi proyek pemberdayaan pesantren oleh LP3ES (Bruinessen et. al., 2006). Kelompokkelompok itu kini begitu berjibun, marak di hampir kelompok masyarakat dalam semua tingkatan, bukan hanya di kota-kota besar dan kota pelajar melainkan kota-kota kecil seperti kecamatan, terutama yang di situ terdapat pesantren (traditional Islamic boarding school). Sebagian mereka memang muncul bagai kekuatan baru dengan strategi baru pula, meski demikian tematema yang diusung tidak lepas dengan apa yang telah mereka bangun selama rejim Orde Baru dengan semi bawah tanah (semi underground). Tulisan ini hanya menyorot beberapa kelompok yang menonjol di beberapa daerah (lihat appendik 1).

Bagi Hefner, misalnya, fenomena demikian tidak hnaya terjadi di Indonesia tetapi di Negara lain. Ia memberikan perspektif optimismenya dari gerakan tersebut:

"In these countries (Turkey, Iran, Morocco, Malaysia and Indonesia, ed.), the movement for a civicpluralist Islam is no longer just a matter of limited-group discussion, Internet chat groups, or tacit pacts with sympathetic government officials; it has become a powerful stream in public politics and culture." (Hefner, 2005, p. 13).

Munculnya generasi baru para aktivis kelompok ini sesungguhnya bersamaan dengan perubahan orientasi secara umum dalam dunia nongovermental organization (NGO) dari community development (CD) ke gerakan atau NGO transformatif (Fakih 1996, p. 105; Eldridge, 1995, p. 25-26). Menurut Fakih, NGO transformatif adalah NGO yang mengagendakan perubahan politik melalui kontra diskursus dan kontra hegemoni dan tidak hanya melalui community development belaka (Fakih, 1996, p. 106107).

Menurut Faqih, kecenderungan ini tidak lepas dari pengaruh perubahan 
orientasi kalangan aktivis non-governmnet (NGO) di tempat lain seperti di Amerika Latin misalnya dan pemikiran ilmu sosial kritis di Eropa. Mereka misalnya terpengaruh oleh pemikiran dan aksi dari Paulo Freire tentang pendidikan kaum tertindas di Amerika Latin dan pemikiran teori politik Antonio Gramsci tentang hegemoni dan intelektual organik serta Jürgen Habermas tentang public sphere, misalnya.

Dalam perspektif masa Orde Baru, kontra diskursus dan kontra hegemoni sebagaimana dimaksud oleh Fakih adalah ketika mereka berhadapan dengan konsepkonsep dan ideologi pembangunan atau developmentalism ideology serta pendekatan keamanan yang diterapkan oleh pemerintah yang berkuasa. Namun gerakan transformatif pasca reformasi itu tidak hanya menekankan pada kontra diskursus dan kontra hegemoni ideologi pembangunan sebagaimana masa Orde Baru. Mereka sudah bergeser pada kontra diskursus dan kontra hegemoni neoliberalisme atau globalisasi di satu pihak dan kecenderungan konservatisme dan fundamentalisme dalam pemikiran Islam dan gerakan, semisal kecenderungan wahabisme dan salafisme di lain pihak.

Meskipun ide-ide demokrasi dan hak-hak asasi secara substansial mereka ambil dari ide-ide Barat dan kemudian ditranformasikan ke dalam ide-ide Islam, tetapi mereka umumnya sangat kritis terhadap relasi yang tidak seimbang antara dunia ketiga dan dunia pertama, serta representasinya di Indonesia antara kebijakan-kenbijakan pemerintah yang cenderung menguntungkan pemilik modal dan berakibat penindasan pada rakyat kecil.

Dengan demikian, dalam aras pemikiran mereka memiliki dua agenda besar, yaitu di satu pihak membangun kritisisme terhadap kecenderungan ketidakadilan dan kesenjangan akibat globalsiasi dan neo-liberalisme baik dalam konteks global maupun nasional dan lokal yang mengakibatkan ketidakadilan.

Di lain pihak mereka berupaya mentrasformasi ide-ide moderatisme dan progresivisme dalam Islam sebagai tanggapan terhadap kecenderungan koservatisme dan fundamentalisme pemikiran dan gerakan keagamaan. Dalam aras praktis, bersamaan dengan penyadaran dan mengorganisir masyarakat atas proses pemiskinan dan ketidakadilan akibat neo-liberalisme dan globalisasi, mereka melakukan kritisisme terhadap penafsiran agama yang sempit dan konsevatif; serta kritisisme terhadap berbagai kebijakan yang kontra kepentingan rakyat miskin. Dalam kerja demikian, di lapangan mereka sering berhadapan dengan organisasi dan aliansi agama yang mapan dan para pemuka kharismatis yang memiliki kekuatan massa untuk melawan mereka, dan kepentingan modal yang sering beralinasi dengan kekuasaan. 
Secara sosial sebagian besar aktivis gerakan ini berasal dari tradisi komunitas dua organisasi Islam tersebar di Indonesia, yaitu Nahdlatul Ulama (NU) dan Muhammadiyah. Bahkan sebagian eskponen gerakan ini merupakan aktivis aktif dari dua organisasi tersebut. Dua organisasi besar ini tumbuh di awal abad ke-19 sebagai respon atas penjajahan dan mengagendakan pembaruan masyatakat Islam. Bedanya, jika NU lebih dikenal sebagai tradisionalis dan berbasis di pedesaan dan pesantren (Islamic traditional boarding school), maka Muhammadiya lebih berbasis pada masyarakat urban dan sekolah modern. Dengan kata lain, dalam berbagai penelitian sosial politik biasanya NU dikategoriakn sebagai kelompok Islam tradisionalis sedangkan Muhammadiyah dikategorikan sebagai kelompok modernis.

Namun, karena keterlibatan mereka di dalam organisasi independen dan NGO tersebut, maka mereka biasanya tidak selalu mengikuti fatwa dan pendapat dari induk organisasinya, baik dalam sikap politik maupun pandangan keagamaan. Demikian juga dalam strategi dan pendekatan dalam perubahan masyarakat. Terkadang bahkan, mereka bertentangan dengan induk organisasinya tersebut.

Sebagai contoh sikap independensi itu adalah respon mereka terhadap fatwa Majelis Ulama Indonesia (MUI) tentang haramnya "pluralisme, sekularisme dan liberalisme" tahun 2005 yang terangterangan menyerang tidak hanya Jaringan
Islam Liberal (JIL) tetapi juga kelompokkelompok progresif ini. Di saat dua ormas besar NU dan Muhammadiyah tidak berkutik menghadapi lembaga agama yang dibiayai pemerintah itu karena sebagian tokoh teras mereka terlibat secara organisasi di dalamnya, GMP tampil menentang dengan berbagai cara mulai dari demonstrasi, mengritik melalui media massa, debat publik dan penerbitan buku (Suaedy dkk., 2006).

Mereka lebih mengacu kepada tokoh-tokoh tertentu di dalam organisasi atau komunitas besar tersebut ketimbang kepada petunjuk dan fatwa resmi organisasi, kecuali yang benar-benar mereka anggap sesuai dengan visi dan agenda mereka. Di kalangan aktivis NU dan pesantren, misalnya, mereka tidak lepas dari pemikiran tokoh progresif seperti Gus Dur atau KH. Abdurrahman Wahid, matan Ketua Umum PBNU, yang sejak dulu banyak memberikan perlindungan dan fasilitasi kepada para aktivis dan intelektual ini. Gus Dur tidak hanya banyak melontarkan dan memberikan pemikiran segar kepada mereka melainkan juga kedekatannya dan kewibawaanya di hadapan pemimpin agama kaum tua, mampu memberikan perlindungan kepada mereka ketika mendapatkan tantangan.

Dari kalangan modernis, Cak Nur atau Dr. Nurcholish Madjid (alm.), mantan Ketua Yayasan Wakaf Paramadina dan Dr. M. Syafii Maarif, mantan Ketua PP Muhammadiyah, adalah dua tokoh 
yang menonjol yang dianggap sebagai patron intelektual mereka. Keduanya bukan hanya dianggap tokoh yang senantiasa menyerukan Islam yang kritis dan toleran melainkan juga menunjukkan independensinya terhadap keputusankeputusan organisasi yang tidak menunjukkan progresivitas seperti keperpihakannya kepada pluralisme dan toleransi. Di luar ketiga tokoh yang menonjol tersebut masih cukup banyak tokoh-tokoh yang lebih muda seperti Masdar F. Mas'udi, Dr. Said Aqiel Siradj, dan banyak tersebar di berbagai daerah.

Sebagian besar aktivis yang memiliki latar belakang pendidikan pesantren (Islamic traditional boarding school) menjadikan mereka memiliki hubungan dan kaitan yang cukup erat dengan para pemimpin agama di masing-masing daerah atau lokal. Karena itulah hubungan ini memiliki keuntungan bagi gerakan ini, karena mereka mendapat dukungan dari mereka (lihat appendik II). Salah satu peran mereka yang penting dalam gerakan ini adalah sebagai inspirator dan pendamping, terutama dalam mensosialisasikan ide-ide pembaharuan keagamaan ke dalam masyarakat, mengingat merekalah yang memiliki massa pengikut lebih banyak di grassroot. Bahkan mereka lah sesunggunnya juru bicara kalangan progresif ini yang menyampaikan ide-ide pokok progresif kepada massa atau umat. Tentang peran tokoh lokal ini akan diurai lebih lanmjut di bawah.
Seperti banyak diketahui, tradisi sosial dan keagamaan di Indonesia masih sangat paternalistik sehingga pengenalan pemikiran dan tafsir baru senantiasa harus melibatkan pada tokoh agama yang hidup di dalam masyarakat. Karenanya, peran mereka sangat penting baik dalam pengenalan ide-ide baru maupun dalam perubahan itu sendiri. Bisa dikemukakan di sini, bahwa sementara para aktivis gerakan progresif berperan sebagai pihak yang banyak memperkenalkan pemikiran dan pendekatan baru tentang perubahan masyatakat, maka para pemimpin agama lah yang menyampaikan dan mempraktikkan perubahan itu kepada masyarakat atau umat Islam.

Sekali lagi Hefner menyatakan:

The success of civil Islam will ultimately depend on more than the ideas of a few good thinkers. In all modern tradition, religious reformation requires a delicate balance between a changing society and its orienting ideas. The ideas must be expansive enough to attract and guide the attention of a fastmoving people (Hefner, 2000, p. 13).

\section{Jaringan isu}

Meskipun kelompok-kelompok tersebut independen dalam hampir segala hal antara satu dengan lainnya tetapi mereka dipersamakan dalam tingkat isu spesifik. Dengan kata lain, apa pun latar belakang dan kegiatan serta lapangan keprihatinan (area of concern) mereka berbeda satu sama lain, tetapi dalam isu ini mereka dibalut oleh perspektif yang sama dalam isu utama. Itu tersebut adalah 
pluralisme, kesetaraan perempuan dan keadilan.

Pertama adalah tentang pluralisme. Meskipun tidak semua kelompok GMP mengambil dan menjadikan isu pluralisme sebagai core orientasi dan kegiatan, tetapi pandangan pluralisme hampir tuntas dalam visi dan misi mereka. Hampir tidak ada yang meragukan tentang keharusan pandangan Islam tentang pluralisme dalam aras konseptual maupun implementasi dalam kemasyarakatan dan kenegaraan. Pluralisme yang dimaksud adalah bahwa setiap kelompok memiliki keyakinan dan berhak atas klaim kebenarannya sendiri dan dalam kehidupan berbangsa dan bernegara semua kelompok memiliki hak hidup sejajar dalam politik dan hukum dengan kelompok lain sebagai manusia maupun sebagai warga bangsa.

Kecuali mereka secara serius mengkaji doktrin Islam tentang yang lain (the others) dan mempromosikan pandangan pluralisme, berbagai regulasi baru yang muncul seiring dengan perubahan cepat di Indonesia menjadi perhatian utama mereka baik secara sendiri-sendiri dengan jaringannya di daerah maupun dalam lingkup nasional. Salah satu isu terpenting berkaitan dengan pluralisme yang menimpa semua daerah adalah tentang kecenderungan regulasi implementasi Syari'ah Islam berkaitan dengan penerapan UU otonomi daerah. Sedangkan dalam level nasional adalah tentang RUU APP (Rancangan UndangUndang Anti-Pornografi dan Pornoaksi) yang telah mengundang solidaritas di antara kelompok tersebut dengan gerakan pro-demokrasi lainnya.

RUU APP menurut para penentangnya bisa mengancam pluralitas budaya dan ekspresi masyarakat dan karena itu membahayakan kehidupan bangsa Indonesia. Sedangkan bagi para pendukungnya, regulasi ini akan menyelamatkan bangsa Indonesia dari keterpurukan karena masalah moral bagi mereka adalah masalah utama yang menyebabkan Indonesia terpuruk secara ekonomi dan politik. Sedangkan implementasi Syari'ah Islam dalam bentuk hukum positif dengan tanpa kritik akan mengancam dipraktrekkannya diskriminasi dan berakibat pada ketiakadilan mendasar.

Kedua adalah isu perempuan. Doktrin Islam yang masih menempatkan perempuan sebagai kelas dua menjadi bahan kajian mendalam di berbagai forum dan penerbitan mereka dengan mengajukan kesetaraan perempuan dalam tafsir keagamaan. Mereka juga sangat kritis terhadap berbagai regulasi yang lahir baik di pemerintah daerah maupun pusat menyangkut posisi perempuan. Berbagai regulasi implemntasi Syari'ah dan RUU APP juga menjadi perhatian karena menempatkan posisi perempuan sebagai salah satu faktor penting terjadinya degradasi moral bangsa. Karena itu, kelompok GMP dan bersama-sama aringan pro-demokrasi lainnya, ibarat koor seluruhnya bersuara menolak berbagai aturan tersebut. 
Ketiga adalah isu tentang keadilan. Isu ini memang sangat luas, tetapi mereka di daerah maupun di pusat sangat waspada terhadap investasi-investasi besar yang mengabaikan partisipasi rakyat dalam pengambilan keputusan dan kemungkinan terjadinya peminggiran terhadap rakyat kecil. Budget pro poor dan gender budget balances dalam penyusunan anggaran daerah dan pusat setiap tahun tidak lepas dari sorotan dan kritik mereka. Tak bisa disangkal, mereka juga terus mengkaji tentang ketidakadilan dan kesewenang-wenangan yang dilakukan oleh Amerika Serikat dan dinamika politik dunia lainnya.

Tiga isu inilah yang hampir selalu menyambungkan mereka dalam kerjasama antar mereka maupun dalam "lingkaran luar" lainnya. Isu itu tidak selalu datang dan lahir dari kelompok itu sendiri melainkan bisa dari lingkaran luar dalam konteks lokal maupun nasional. Barulah kemudian mereka biasanya menyambutnya bersama-sama.

\section{Isu lintas kelompok}

Di luar tiga isu pokok yang pada umumnya menjadi prthstisn utama GMP juga terdapat isu-isu yang yang bersifat lintas. Artinya, isu ini biasanya dikerjakan oleh kelompok pro demokrasi lainnya atau NGO pada umumnya, tetapi karena pertemuan di lapangan mereka masuk di dalamnya. Kelompok GMP biasanya menjadi katalisator dengan para tokoh masyarakat dan tokoh agama setempat ketika mereka mengalami kesulitan dalam pelibatan mereka.

Beberapa isu penting yang patut ditunjukkan di sini adalah, Pertama, tafsir dan implementasi Islam tentang pandangan pluralisme dan kesetaraan perempuan. Gerakan dan kelompokkelompok pro demokrasi yang tidak memiliki cukup latar belakang pengetahuan tentang Islam mengalami kesulitan berarti dalam menjelaksan kepada pemimpin agama dan komunitas Muslim tentang kesetaraan gender dan pluralisme. Ini disebasbkan karena masih dominannya tafsir agama tentang kesenjangan realsi laki-laki perempuan dan relasi antar agama dalam teks-teks keagamaan Islam. Maka, diperlukan tingkat pengetahuan agama dan keterampilan tertentu dari para aktivis tersebut dalam membangun aliansi dan pendekatan terhadap stake holder di daerah itu. Salah satu pendekatan yang paling efektif adalah dengan para tokoh dan pemimpin agama lokal yang telah memiliki kesadaran tertentu tentang kesetaraan gender dan pluralisme.

Kedua, adalah isu korupsi. Ini juga tidak kalah rumitnya karena seringkali para pemimpin lokal pelaku korupsi dengan sengaja maupun tidak berjejaring dengan para pemimpin agama dan mereka yang kharismatis. Maka tidak mudah pula untuk serta merta melakukan kritik dan control kecenderunga korupsi di tingkat daerah tanpa memiliki hubungan yang cukup baik dengan para tokoh agama tersebut. 
Ketiga adalah budget daerah. Tiga isu terpenting dalam budget daerah, yaitu budget untuk perempuan, budget pro poor termasuk di dalamnya untuk pendidikan, dan kontrol terhadap budget untuk para pejabat eselon ketiga ke atas yang seringkali berlebihan dan melampaui kebutuhan untuk pengangkatan kemiskinan dan pemerataan pendidikan.

GAMBAR I:

GAMBARAN LINGKARAN KATEGORI ISU

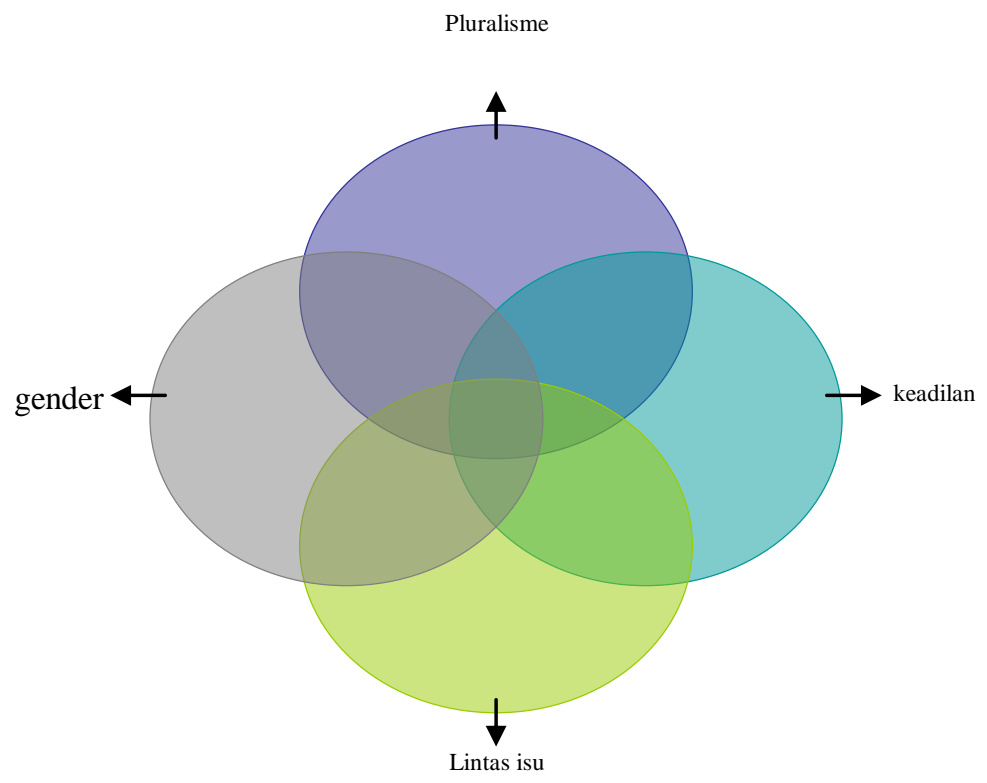

\section{Pola Network}

Di sisi lain, hampir di semua daerah dan isu, masing-masing kelompok ini memiliki hubungan tertentu dengan tokoh-tokoh lokal yang seringkali berfungsi sebagai back up. Para tokoh lokal tersebut biasanya memiliki basis cukup kuat di daerahnya atau memiliki penguasaan atas isu-isu tertentu. Misalnya isu tentang kesetaraan perempuan dalam Islam, maka akan segera bisa ditunjuk KH. Hussen Muhammad dan Faqih Abdulqodir, keduanya di Cirebon; KH. Muhyiddin Abdussomad asal Jember; Ny
H. Ruqoyah di Situbondo; TGH Subhi Sasaki di Lombok; serta Ibu H. Sinta Nuriyah di Jakarta dan sebagainya.

Di samping mereka otoritatif dalam isu keseteraan perempaun di kalangan kelompok progresif juga menjadi tokoh progresif di daerah masing-masing. Demikian halnya dalam isu demokrasi dan hak asasi jumlahnya jauh lebih banyak, seperti KH. Afiffuddin Muhadjir di Situbondo, Prof. Qasim Mattar dan KH Imran Anwar Muin Yusuf di Sulawesi Selatan; Tengku Faesal dan Fuad Mardlatillah di Aceh, KH Maman Imanul 
Haq Faqih, Acep Zamzam Noor dan KH.

Thontowi Djauhari di Jawa Barat, serta

KH Dian Nafi di Solo, KH. Bisri Mustafa di Lasem, serta $\mathrm{KH}$ Mahfud Ridwan di Salatiga.

\section{GAMBAR II:}

LAPISAN KEANGGOTAAN DARI TERDALAM SAMPAI TERLUAR

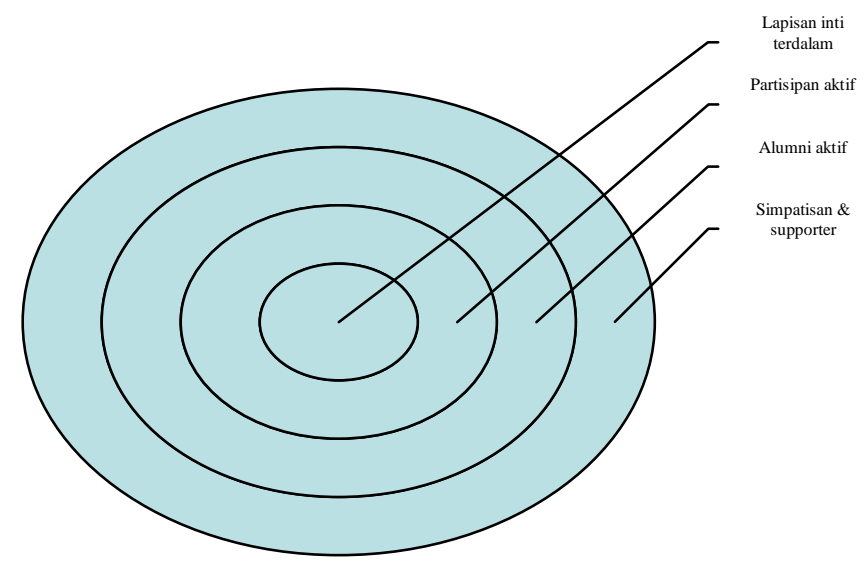

GAMBAR III:

GAMBARAN JARINGAN DALAM KONTEKS LOKAL

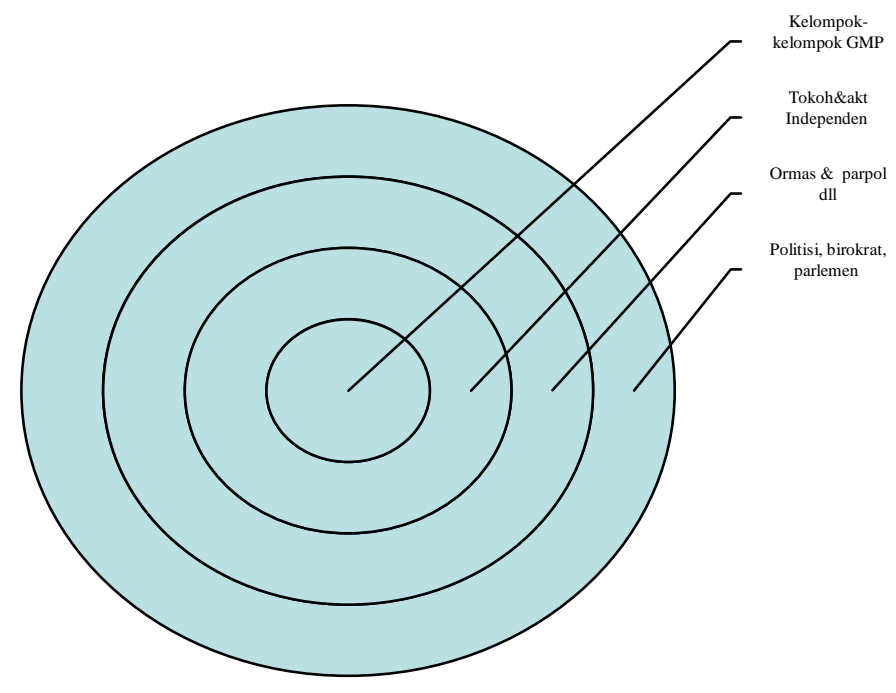

Di samping itu sebagian para tokoh lokal dan kiai tersebut juga memiliki spesialisasi dalam kategori keahlian dalam praktik atau pengembangan sosial, seperti spesialis bidang pengembangan pendidikan K. Bahrudin di Salatiga, kebudayaan KH. Maman dan K. Acep di Jawa Barat, bidang pertanian $\mathrm{KH}$. Mahfudz Ridwan di Salatiga; perdagangan KH. Hasan di Yogyakarta, juga bidang intelektual dalam topik tertentu. (Lihat Appendiks 2). 
Memang tidak atau belum ada jaringan yang bersifat formal Muslim progresif dalam arti memiliki ikatan khusus dan terbangun organisasi formal, kecuali mailing list Islamprogresif@yahoogroups.com yang mendiskusikan berbagai masalah secara terbuka dan menyangkut topik apa saja sehingga tidak ada bedanya dengan mailing list yang lain seperti Islamliberal@yahoogroups.com dan lainnya.

Tetapi kelompok tersebut diikat oleh kesamaan concern dan isu sehingga terbangun kerjasama yang terus menerus. Terkadang isu itu secara khusus menyangkut kelompok tertentu seperti tentang pluralisme, kesetaraan perempuann atau pendidikan, tetapi kenyataannya isu-isu tersebut selalu mengundang kerjasama baik dalam ide maupun dalam gerakan. Beberapa jaringan semi formal yang terbangun di tengah jalan dan bersifat lintas isu, kelompok dan lintas wilayah yang sudah berumur cukup lama misalnya jaringan "advokasi KUB" yang melahirkan berbagai pertemuan dan mailing list (advokasikub@yahoogroups.com) yang masih hidup hingga sekarang selama hampir empat tahun. Sebagian besar aktivis di Indonesia tahu tentang mailing list, serta fungsi dan aktivitasnya.

Mula-mula mailing list dan jaringan ini lahir karena concern atas ancaman yang sama jika sebuah regulasi tentang hubungan antar agama diambil alih oleh
Negara dengan melahirkan regulasi formal tentang itu (RUU KUB-Rancangan Undang-undang Kerukunan Antar Ummat Beragama). Advokasi ini berhasil membatalkan lahirnya regulasi itu, meskipun pemerintah dengan regulasi lain secara tidak langsung tetap mengontrol hubungan antar agama tersebut melalui "Forum Kerukunan Antar Agama (FKUB)" yang diatur melalui SKB (Surat Keputusan Bersama) Menteri Agama dan Menteri Dalam Negeri. Forum advokasiKUB terakhir ini masih menjadi bagian dari advokasi yang berjalan bukan hanya untuk KUB melainkan tindak dan kebijakan diskriminasi serta pelanggaran terhadap hak-hak kepercayaan dan keberagamaan warga negara.

Jaringan ini lebih bersifat informatif. Aktivis Muslim dan NGO dari berbagai daerah di Jawa maupun di luar Jawa, memberikan berbagai informasi tentang kasus dan perkembangan di daerah dan wilayahnya yang perlu mendapatkan perhatian dari teman-teman lain melalui advokasi-kub@yahoogroups.com. Jika ada kasus yang perlu mendapatkan perhatiaan dan advokasi bersama maka sebagian teman di daerah akan melakukannya sesuai dengan ketersediaan tenaga dan biaya. Keterlibatan teman di daerah lain atau bahkan di daerah sendiri juga berkaitan dengan fokus program dan kegiatan para aktivis dan NGO itu sendiri. Terkadang perhatian terhadap sebuah kasus diberikan lebih banyak oleh teman di luar daerah ketimbang sesama aktivis 
daerah itu sendiri, disebabkan karena fokus perhatian dan program yang sedang dikerjakan oleh mereka.

Dengan demikian efektivitas jaringan tersebut tergantung dari kasus dan isu yang ditangani dan dikerjakan oleh kelompok tertentu dalam jaringan. Jaringan yang tergabung dalam mailing list advokasi-kub@yahoogroups.com dengan demikian lebih bersifat tematik dan kasusistik, namun informasinya pada umumnya akan selalu terdistribusikan dalam mailing list ini.

Di lain pihak, dengan tidak adanya jaringan formal dengan menggunakan nama kelompok dan Gerakan Muslim progresif ini justeru mereka lebih luwes untuk terlibat di berbagai jaringan yang dipersamakan dalam concern dan isu. Dalam konteks terbangunnya jaringan isu dan daerah tertentu, terkadang suatu kelompok menempati lingkaran sentral karena isu yang dimunculkan menjadi bagian dari core programnya, tetapi di saat lainnya akan menjadi lingkaran luar lainnya. Tidak menjadi masalah dalam merespon terhadap berbagai isu, apakah mereka sebagai pengambil inisiatif atau sekadar sebagai partisipan.

Gambar IV adalah gambaran jaringan lokal, regional dan nasional.
Masing-masing lingkaran terdiri dari lingkaran dalam kelompok dan lingkaranlingkaran luar lainnya, menurut daerah. Gambar tersebut tidak selalu menunjukkan bahwa suatu kelompok tertentu selalu berada di pusat lingkaran, melainkan kadang di tengah, di lapisan dua dan terkadang di lapisan paling luar. Tiga lingkaran di bawah ini hanya contoh irisan yang terjadi antar jaringan di lokal dalam konteks regional dan nasional.

Jaringan yang bersifat daerah atau lokal juga terbentuk untuk menanggapi berbagai isu dan pada umumnya ditujukan untuk melakukan advokasi kasus-kasus tertentu baik yang bersifat spontan maupun permanen. Di Jawa Timur misalnya terbangun JLAD (Jaringan Islam Anti-Diskriminasi), di Lombok barat terbentuk jaringan pemuka agama untuk advokasi budget pro poor dan budget pro women yang mereka sebut Dewan Pemantau Budget Daerah. Juga di Sulawesi Selatan terbentuk jaringan untuk memantau penerapan Syari'ah Islam dan kekerasan agama, meskipun mereka tidak memberikan nama tertentu; hal yang sama terjadi di Jawa Barat, salah satunya Forum Sabtuan di Cirebon yang fokus pada dialog antar agama dan advokasi minoritas korban diskriminasi. 


\section{GAMBAR IV: \\ GAMBARAN JARINGAN NASIONAL}

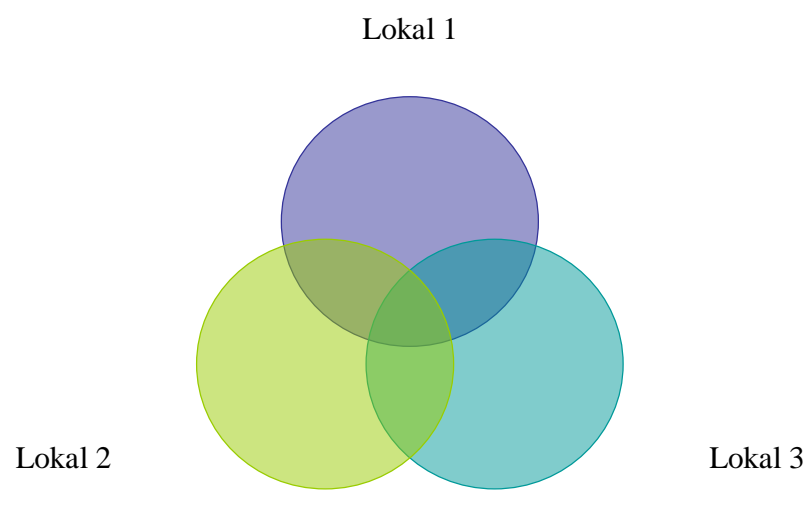

\section{Kelemahan dan kekuatan}

Sebagai institusi sosial maupun jaringan, Gerakan Muslim Progresif (GMP) bisa dikatakan sebagai institusi sosial paling muda di antara institusi sosial lainnya di Indonesia, seperti organisasi massa Islam, lembaga pendidikan, pelayanan kesehatan, media, termasuk partai politik. Karena itu mereka masih merumuskan dan menajamkan orientasi dan ideologi mereka. Sering menjadi dilema antara transformasi ide-ide progresif yang mengharuskan adanya keterbukaan dan liberalisasi dalam ide-ide keagamaan Islam dengan kenyataan dominasi neo-liberalisme dan ketidakadilan internasional yang sering tidak bisa dihindari impact-nya dalam skala nasional. Sementara ideologi kiri dan sosialisme kehilangan argumentasi dan bukti untuk meningkatkan kesejahteraan rakyat dan memberi jaminan hidup lebih baik, terutama bagi kalangan miskin.

Dalam konteks liberalisasi, gerakan ini membedakan diri dengan kelompokkelompok Islam yang cenderung kepada liberalisme dan sebaliknya mengklaim diri sebagai liberation dan bukan liberalism. Pembebasan yang mereka maksud bukanlah membiarkan pengaruh pasar dan globalisasi tanpa reserve. Tidak sebagaimana kelompok yang mengikuti arus liberalisme, mereka sangat kritis terhadap investasi asing dan perlakuan mereka terhadap buruh serta penguasaan sebuah perusahaan investasi. Karena itu, kritisisme mereka terhadap pemerintah termasuk pemerintah daerah mencakup masalah ini. Pandangan kritis yang juga terlihat dalam pandangan mereka terhadap serangan Amerika Serikat terhadap Irak.

Namun, mungkin karena kemudaan usia, sehingga sebagian besar produk dan 
program mereka lebih banyak pada ranah discourse, workshop dan training ketimbang respon langsung terhadap realitas sosial dan perubahan politik yang kongkrit. Mereka tampak ragu-ragu untuk melibatkan diri dalam pengambilan keputusan dan perubahan politik serta kebijakan secara langsung. Ada kesenjangan yang cukup signifikan antara ranah discourse reformasi ide-ide keagamaan dengan keterlibatan langsung terhadap perubahan sosial politik secara langsung.

Kenyataan ini akan sangat kontras jika dibandingkan dengan gerakan konservatisme dan fundamentalisme yang tanpa ragu-ragu menuntut penerapan tafsir tekstual mereka atas agama dan Kitab Suci dalam kenyataan sosial politik, baik melalui legislasi maupun tekanan massa. Kelompok yang disebut terakhir ini bahkan tidak ragu untuk berkoalisi dengan kelompok yang secara teoritik bermusuhan dengan mereka, seperti pemeluk agama lain dan kelompokkelompok yang secara politik saling berseberangan, untuk meraih kekuasaan dan mempengaruhi kebijakan.

Tetapi penekanannya pada discourse boleh jadi sebagai bagian dari pencarian landasan ideologi dan orientasi gerakan yang lebih kuat. Ada perbedaan yang cukup menyolok pendekatan atas ajaran Islam di kalangan aktivis Muslim progresif dengan gerakan Islam konvensional dan konservatif, yaitu penekanannya pada pendekatan filsafat dan ilmu-ilmu sosial, bukan fiqh atau hukum sebagaimana pendekatan dalam gerakan Muslim konvensional. Sementara kalangan GMP hendak mempertanyakan doktrin-doktrin sosial dan hukum Islam bagi efektivitas dan impact-nya bagi kesejahteraan rakyat, maka kalangan konservatif dan fundamentalis justeru hendak mengimplementasikan apa yang ada di dalam doktrin-kontrin dan ajaran Islam konvensional dengan mengabaikan impactnya bagi rakyat.

Gerakan MP ini memang banyak menyerap pendekatan filsafat dan ilmu sosial terhadap ajaran Islam yang banyak berkembang dalam kajian-kajian Islam mutakhir baik dari Barat maupun dari Timur Tengah. Sebaliknya kalangan konservatif lebih banyak menyerap ajaran ayang dikembangkan oleh kalangan konservatif fundamentalis seperti Ikhwanul Muslimin dari Mesir, Wahabi dari Saudi Arabia dan Jama'at al-Islamy dari Pakistan. Namun, pandangan yang cenderung terbuka dan tak mengenal sekat agama dan kelompok, membuat GMP lebih mudah berhubungan dan menjalin kerjasama, termasuk untuk mengakomodasi isu-isu yang tidak berkaitan langsung dengan doktrin dan pemikiran Islam. Sementara di kalangan konservatif dan fundamentalis terjadi sebaliknya.

\section{Refleksi dan rekomendasi}

Demokratisasi di negeri Muslim sangat sulit untuk tidak dikaitkan dengan 
perkembangan pemikiran Islam dalam merespon perubahan masyarakat dan globalisasi. Gerakan Muslim Progresif adalah salah satu unsur penting untuk mendorong kekuatan civil society dalam proses demokratisasi tersebut. Pentingnya peran mereka sebagai apa yang oleh Hefner disebut "mediating institusions" dalam tarik-menarik antara tuntutan rakyat dan kemauan penguasa serta partai politik, serta kecenderungan pengaruh kalangan radikal dan fundamentalis dalam proses demokratisasi di pihak lain.

Dalam konteks gerakan Islam, GMP berperan penting dalam mencegah laju dan pengaruh konservatisme yang bisa mengundang set back dalam proses demokratisasi. Yaitu, memberikan cara pandang berbeda yang lebih terbuka dan toleran atas kecenderungan politik identitas dan politik aliran dalam partai politik. Hal ini akan mencegah bersatunya politik identitas dan kekuasaan politik dalam suatu kekuasaan pemerintahan. Karena kalau hal itu terjadi, maka akan mencegah impact keadilan bagi semua orang dalam demokrasi. Karena itu usaha memperkuat gerakan ini menjadi penting. Gerakan MP memerlukan kondisi dan situasi yang memungkinkan berkembangnya ide dan tafsir alternatif atas kenyataan dan agama. Dalam konteks GMP di Indonesia, kelemahan dalam memobilisasi sumberdaya lokal menjadi kelemahan pokok. Diperlukan mediasi antara para aktivis dengan massa grassroot.
Sedangkan untuk membangun jaringan yang efektif di antara kelompok tersebut memang tidak diperlukan sebuah institusi formal layaknya ormas atau parpol karena itu justeru dikhawatirkan akan berujung pada perebutan identitas dan posisi dalam struktur organisasi. Yang diperlukan justeru semacam forum bersama secara regular baik yang bersifat lokal maupun nasional lintas aktivis dan lintas isu untuk membangun komitmen bersama secara berkesinambungan dan mencari fokus dan prioritas bersama seiring dengan perkembangan masyarakat dan tuntutan peran. Forum seperti ini bisa diprakarsi oleh suatu kelompok tertentu bisa juga merupakan kerjasama antar beberapa kelompok.

Forum seperti ini juga penting untuk menjaga dan mengikat pada tokoh lokal yang memiliki akar massa grassroot dan penguasaan atas isu tertentu tetapi mereka tidak memiliki ketrampilan dan waktu untuk terus menerus mengikui aktivitas dan isu yang ditekuni oleh gerakan MP. Peran mereka dalam menyambungkan antara ide dan gagasan aktivis gerakan sangat penting agar sampai kepada masyarakat lebih luas. Karena proses demokrasi tidak akan terjadi tanpa adanya, meminjam istilah Oliver Roy, "para demokrat" yang bekerja di lapangan dan terlibat langsung dalam masyarakat. Dalam konteks ini, pernyataan Oliver Roy (2004) berikut layak disimak:

The central issue is about the real actors of democratization. One 
should be careful not to read too much into what is said by some progressive intellectuals who have some good ideas as Western political commentators, but are either cut off from their own society or, more often, are themselves (without acknow-ledging it) part of tradition networks, and combine rhetorical democracy with social patronage. We would do better to address the real actors in the process, even if they are motivated by different ideas. Such an approach would help us to move beyond the usual predicament of the reference to 'civil society.' (Roy, 2004: 82)

Tantangan utamanya adalah, bagaimana GMP ini menjadi gerakan massa untuk perubahan. 


\section{DAFTAR PUSTAKA}

Anwar, M. Syafi'i, 1995, Pemikiran dan Aksi Islam Indonesia, Sebuah Kajian Politik tentang Cendekiawan Muslim Orde Baru, Jakarta, Paramadina.

Barton, Greg, 2004, Indonesia's Struggle, Jemaah Islamiyah and the Soul of Islam, Sydney, University of New South Wales.

, 1999, Gagasan Islam Liberal di Indonesia, Pemikiran Neo-Modernisme Nurcholish Madjid, Djoban Effendi, Ahmad Wabib dan Abdurrabman Wahid (trans.), Jakarta, Paramadina.

Bruinessen, Martin van, 2004, "PostSoeharto Muslim Engagements with Civil Society and Democratization" in Samuel, Hanneman and Nordholt, Henk S., Indonesia in Trasition, Retbingking 'Civil Society', 'Religion', and 'Crisis', Yogyakarta, Pustaka Pelajar, pp. 37-66.

Bruinessen, Martin van, and Wajidi, Farid, 2006, "Syu'un ijtima'iyah and the kiai rakyat: Traditionalist Islam, Civil Society and Social Concerns," dalam Henk Schulte Nordholt (ed.), Indoensian Transitions, Yogyakarta: Pusataka Pelajar (hlm. 205-248).

Budiman, Arief and Törnquist, Olle, 2001, Aktor Demokrasi, Catatan tentang Gerakan Perlawanan di Indonesia, Jakarta, ISAI.

Burke, Edmud and Ira M. Lapidus (ed.) 1980, Islam, Politics and Social Movements, Berkeley, Los Angeles, London: University of California Press.

Bush, Robin L., 2002, Islam and Civil Society in Indonesia: the Case of the Nabdlatul Ulama, Doctor of Philosophy Dissertation at University of Washington (unpublished).
Cohen, Jean L. and Arato, Andrew 1994, Civil Society and Political Theory Massachusetts, The MIT Press.

Clark, John, 1997, NGO dan Pembangunan Demokrasi (trans.), Yogyakarta, Tiara Wacana.

Diamond, Larry and Plattner, Marc F. (ed.), 1996, The Global Resurgence of Democracy, Maryland, Johns Hopkins University Press.

Effendy, Bahtiar, 1998, Islam dan Negara, Transformasi Pemikiran dan Praktik. Politik Islam di Indonesia, Jakarta, Paramadina.

Eldrigde, Philip J., 1995, Non-Government Organizations and Democratic Participation in Indonesia, New York, Oxford University Press.

Fakih, Mansour, 1996 (dissertation) Masyarakat Sipil untuk Transformasi Sosial, Pergolakan Ideologi LSM Indonesia, Yogyakarta, Pustaka Pelajar.

Fealy, Greg, 2005, Joining the Caravan? The Middle East, Islamism, and Indonesia, Australia, Lowy Institute for International Policy, paper 05.

Ganie-Rochman, Meuthia, 2002, An Uphill Struggle, Advocacy NGOs under Soebarto's New Order, Jakarta, LabSosio.

Guan, Lee Hock (ed.), 2004, Civil Society in Southeast Asia, Singapore, ESIAS.

Gunawan, Jamil et al., 2005, Desentralisasi, Globalisasi, dan Demokrasi Lokal (Decentralisation, Globalisation and Local Democracy), Jakarta, LP3ES.

Hefner, Robert W. 2000, Civil Islam Muslims and Democratization in Indonesia Princeton, Princeton University Press.

(ed.) 2005, "Introduction: Modernity and the Remaking of 
Muslim Politics" dalam Hefner R.W. (ed.) Remarking Muslim Politics, Pluralism, Contestation, Democratization Princeton, Princeton University Press.

Noor, Fariz A., 2006, Islam Progresif: Peluang, Tantangan, dan Masa Depannya di Asia Tenggara, Yogyakarta, SAMHA.

Rahardjo, M. Dawam, 1999, Masyarakat Madani: Agama, Kelas Menengah dan Perubahan Social, Jakarta: Paramadina dan LSAF.

Roy, Olivier, 1995, Failure of Political Islam, Cambridge MA, Harvard University Press.

-----, 2004, Globalized Islam, The Search for A New Ummah New York, Columbia University Press.

Rumadi, 2006, Post Tradisionalisme Islam: Wacana Intelektualisme dalam Komunitas $\mathrm{NU}$, disertasi untuk $\mathrm{PhD}$. di UIN Jakarta (tidak diterbitkan).

Safi, Omid (ed.), 2003, Progressive Muslims, On Justice, Gender, and Pluralism, Oxford, Oneworld.

Sajoo, Amyn B. (ed.), Civil Society in The Muslim World, Contemporary Perspectives, London, I.B. Tauris Publishers

Salim HS, Hairus et. al., 1999, Kultur Hibrida; Anak Muda NU di Jalur Kultural, Yogyakarta:LKiS.

Samuel, Hanneman and Nordholt, Henk S., Indonesia in Trasition, Rethingking 'Civil Society', Religion', and 'Crisis', Yogyakarta, Pustaka Pelajar, pp. 3766.

Silliman, G. Sidney and Lwela Garner Noble (ed.), 1998, Organizing for Democracy, NGOs, Civil Society, and the Philippine State, University of Hawaii Press.
Suaedy, Ahmad dkk. (ed.), 2006, Kala Fatwa Jadi Penjara, Jakarta, The Wahid Institute.

Uhlin, Anders, 1995, Democracy and Diffusion, Transnational Lesson-Drawing among Indonesian Pro-Democracy Actors, Sweden, Team Offset.

Woodward, Mark, 2001, "Indonesia, Islam and the Prospect of Democracy" SAIS Review Vol. XXI, No. 2 (Summer-Fall 2001), hlm. 29-37.

www.wahidinsitute.org

www.lkis.or.id

www.lakpesdam.or.id

www.nu.or.id

www.islamlib.com 